UDC: $272-77-726.1 / .2: 355.48]$ (477.83-25)".../1439"

\author{
Roman Ivashko, \\ Postgraduate Student, \\ Ivan Franko National University of Lviv (Ukraine, Lviv), \\ romanivashko1@gmail.com, \\ orcid.org/0000-0002-7265-464X
}

\title{
THE BISHOPS OF THE LATIN METROPOLITANATE OF LVIV IN MILITARY CONFLICTS ON THE EVE OF THE FLORENTINE UNION
}

The article deals generally with one aspect of the history of the Middle Ages of Central and Eastern Europe and the history of the lands of Rus' in particular. In recent years, particular attention has been paid to the participation of the Latin bishopric in the political life of the Crown of Poland and the Grand Duchy of Lithuania by Polish researchers Krzysztof Prokop and Tomasz Graff.

In principle, the population of the respective territory, where the Metropolitanate of Lviv was located, was forced to resist the Tatar raids, to participate in the Polish-Teutonic, Hussite and Švidrigaila's wars, and to accept the challenge of the threat of the Ottoman conquest. In these conflicts, the Latin bishop of the lands of Rus' was generally on the side of the King of Poland Władysław II Jagiełło.

It was find out which prelates were involved in military conflicts and forms of participation in its. First of all, it was the Metropolitan of Lviv Jan Rzeszowski. His evangelistic, inquisitorial, fiscal and diplomatic services were directed against the Teutonic Order, Hussites and "schismatics." The Metropolitan Jan Rzeszowski officially announced the transfer of the Metropolitan Cathedra from Halych to Lviv, which walls were supposed to protect against Tatar raids.

Diplomatic service was also provided by Bishops of Chołm Jan Biskupiec, Kamianets Zbigniew of Lapanów, Kyiv Michał Trestka, Lutsk Andrzej from Plońsk, and Bai Jan Ryza. Hussites were opposed by Bishop of Przemyshl Maciej Janina, and the "mysterious" Bishop of Chotm, Andrzej de Laschis. The Bishop of Lutsk Andrzej of Plońsk was episodically in the center of military and political vicissitudes. Obviously, the Bishop of Kamianets Pavel of Bojańczyc acted most 
radically who taking a direct part in organizing the arrest of the Lithuanian governor in Podillia.

Military confrontations testified that the ecclesiastical jurisdiction of the Metropolitan of Lviv and its subordinate bishops in the territory of the Grand Duchy of Lithuania was rather formal. In reality, their jurisdiction extended to Kamianets and Lutsk. In many cases, there was a confrontation in the territory in which the division and religious affiliation of Catholics on the one hand and "schismatics", pagans or heretics on the other was also sustained.

Keywords: the Latin Metropolitanate of Lviv, Teutonic Order, the Hussite Wars, the Lithuanian Civil War (the Wars of Švitrigaila), Tatar raids, the Ottoman Threat.

Роман Івашко, аспірант, Львівський національний університет імені Івана Франка (Україна, Львів), romanivashko1@gmail.com, orcid.org/0000-0002-7265-464X

\section{ЄПИСКОПИ ЛЬВІВСЬКОї МИТРОПОЛІї ЛАТИНСЬКОГО ОБРЯДУ У ВІЙСЬКОВИХ КОНФЛІКТАХ НАПЕРЕДОДНІ ФЛОРЕНТІЙСЬКОЇ УНІЇ}

Стаття присвячена одному з аспектів історії середніх віків Центрально-Східної Європи та історії руських земель зокрема. В останні роки окрему увагу на участь латинського єпископату у політичному житті Корони Польської та Великого князівства Литовського звернули польські дослідники Кшиштоф Прокоп та Томаш Графф.

Населення відповідної території, де знаходилась Львівська митрополія, було змушене протистояти татарським набігам, брати участь у війнах з Тевтонським орденом, гуситських, Свидригайлових війнах та прийняти виклик загрози Османського завоювання. Латинський єпископат руських земель у цих конфліктах загалом був на стороні польського короля Владислава ІІ Ягайла.

В даному дослідженні вдалося з'ясувати які саме прелати брали участь у військових конфліктах та форми участі у них. Перш за все, це був львівський митрополит Ян Жешовський. Його євангелізаторська, інквізиційна, фіскальна та дипломатична служби були спрямовані проти Тевтонського ордену, гуситів та "схизматиків". Митрополит Ян Жешовський офіційно проголосив перенесення митрополичої катедри з Галича до Львова, мури якого мали захищати від татарських набігів.

Дипломатичну службу здійснювали також єпископи Холма - Ян Біскупєц, Кам'янця - Збігнєв за Лапанова, Києва - Міхал Трестка, Луцька Анджей з Плонська, Баї - Ян Риза. Проти гуситів діяли єпископ Перемишля Мацєй Яніна та загадковий єпископ Холма Анджей de Laschis. Епізодично у центрі військово-політичних перипетій опинився єпископ Луцька -Анджей з Плонська. Вочевидь, найрадикальніше діяв єпископ 
Кам'янця - Павел з Боянчиц, який взяв безпосередню участь в організації арешту литовського намісника на Поділлі.

Військові протистояння свідчили про те, що церковна юрисдикція Львівського латинського митрополита та підлеглих йому єпископівсуфраганів на території Великого князівства Литовського була радше формальною. Реально їх юрисдикція сягала умовно Кам'янця та Луцька. В багатьох випадках на відповідній території була конфронтація при якій був витриманий також поділ і за релігійною ознакою на католиків з однієї сторони та "схизматиків", язичників чи єретиків з іншої.

Ключові слова: Львівська митрополія латинського обряду, Тевтонський орден, Гуситські війни, Громадянська війна у Великому князівстві Литовському (Свидригайлові війни), татарські набіги, Османська загроза.

The principles of the bishops' vassal dependence on secular lords were first defined by the Concordat of London on August 1,1107, at the White Tower. The youngest son of William the Conqueror (1066-1087), the King of England Henry I (1100-1135), surrendered the right to appoint bishops and abbots in favor of Pope Paschal II (1099-1118). But vassal oath on a ground of allotment was to be made by bishops and abbots to the King (Bettenson, 1967: 218). The Concordat of Worms on September 23, 1122, was the second arrangement that reiterated the principles of separation of powers between the Pope and the secular ruler (Bettenson, 1967: 154). But even before that, bishops already participated in the defense of Paris in 885 and the First Crusade (1097-1099). In the following centuries, bishops participated in the landmark battles in particular at Los Navas de Tolosa on July 16, 1212, and Grunwald-Tannenberg on July 15, 1410. Besides that the archbishops of Mainz, Trier and Cologne elected Emperors of the Holy Roman Empire (IFS, Privilegien 107: 26-28). In addition, the growth of the dynastic possessions of the Jagiellonian dynasty was also conditioned by the policy of the Bishop of Kraków Zbigniew Oleśnicki (1423-1455), who had been saved life of the King Władysław II Jagiełło (1386-1434) at the battlefield of Grunwald-Tannenberg being the royal clerk (BJ, Rkps 33: 254 (253)). Instead, the examples of political, diplomatic and military activity of pastors of the Latin Metropolitanate of Lviv have not been abstracted so far.

The main written sources on the subject are the decrees of the Councils of Constance (1414-1418) and Basel (1431-1449) (Pietras, Baron, 2003), Medieval letters on parchment and their later copies, many of which are in the archives of Warsaw, Kraków and Lviv (Kupchynskyi, Ruzhytskyi, 1972). Many of its had already been published or digitized. The notifications about the activity of the pastors of the Lviv Church and their subordinates are also found in the chronicle of Jan Długosz (1415-1480) and the chronicle of the city of Lviv written by Bartolomey Zimorovich (ЦДІАЛ України, ф. 52, оп. 2, спр. 1157). The last translation of the chronicle in Ukrainian was made by Nataliya Tsariova (Zimorovych, 
2002). Leontii Voitovych's book on the formation of the Crimean Tatar people also contains information about Mongol and Tatar raids on Rus' lands in the early $15^{\text {th }}$ century (Voitovych, 2009: 177-186). The latest generalizations regarding the participation of the Crown of Poland in the Hussite Wars and in the fight against the threat of Ottoman Turks conquest were made by John Jefferson (Jefferson, 2012). The book of the Moscow historian Sergei Poliekhov has also recently been published (Poliekhov, 2015). This is a real challenge for representatives of the Ukrainian historiography, including Olena Rusyna, Valerii Zema and Natalia Yakovenko (Rusyna, 2003: 12-13; Zema, 2018: 78-79; Yakovenko, 2005: 144149). Recent studies on bishops of the Latin Metropolitanate of Lviv belong to Krzysztof Prokop (Prokop, 2001; Prokop, 2007; Prokop, 2010). The most active researcher in the history of the Metropolitanate of Lviv in recent years is Tomasz Graff (Graff, 2008a; Graff, 2008b; Graff, 2010).

The history of the Grand Duchy of Lithuania is being rethought by new generations of researchers. The author submits particularly results of researching the features of participation of the bishopric of the Latin Metropolitanate of Lviv in the confrontation between the Crown of Poland and the Grand Duchy of Lithuania with the Teutonic and Livonian Orders, the Hussite Wars, Lithuanian Civil War of 1432-1438 (the Wars of Švitrigaila) and a conquest of the Ottoman Turks of the Balkans, which affected at least the lands of Moldova (Ivashko, 2019: 46-48). It was left aside events related to activities of the Metropolitan of Kyiv and All Rus' Photius (1408-1431), whose sit was in Moscow, and the attempts of the Grand Duke Vytautas the Great to create the autocephalous Church in the Grand Duchy of Lithuania. However, in this generalizing English-language article some materials of national and foreign archives are included more broadly.

\section{Tatar raids}

Legal introduction of structures of the Latin Church in South-Western Rus' was the result of the dynastic crisis in the Kingdom of Rus'. The crisis was to some extend caused by the weakening of the Kingdom by the constant Tatar attacks. In this situation Latin clergy in the region was to become the mainstay of the Hungarian King Louis the Great (1342-1382). Apostolic See, guided by the realities of the $13^{\text {th }}$ century, disposed of to create the Latin Metropolitanate of Halych at the request of the Hungarian side. But this city had been already lost it political significance and the Hungarian Governor Oppelni László (1372-1378) requested the transfer of the Cathedra of the Latin Metropolitan from unprotected Halych to the fortified Lviv, which at that time had real political and economic importance (Theiner, 1860: 719). In fact, the pro-Hungarian Metropolitans Maciej of Eger (1375-1380) and Bernard (1385-1390) immediately lived in Lviv, not in Halych. The case of the official transfer of the Cathedra was completed on the request of the King of Poland Władysław II Jagiełło to the (anti)Pope John XXIII (1410-1415) (Theiner, 1861: 5-6, 13). The King was the husband of the Polish Queen (King) 
Jadwiga (1384-1399) who entered with the Polish troops into the land of Lviv in 1387 when she had been young girl yet. The first official Metropolitan of Lviv was Jan Rzeszowski (1414-1436) who solemnly proclaimed the transfer the Cathedra to Lviv in the Cathedral of Lviv on the eve of Christmas of 1414 (ЦДІАЛ України, $\phi .52$, оп. 2, спр. 1157, арк. 56). Shortly thereafter, the emir of the Golden Horde Edigey (c.1345-1419) robbed Kyiv and the territories west of the Dnieper (Krekoten', Shevchuk, Ivanchenko, 2006: 111). The Polish troops could not fatally overcome Tartars even at the end of the outlined period, after being crushed at Red Field by them (MNK VIII-rkps-193: 29(15); ЦДІАЛ України, ф. 52, оп. 2, спр. 1157, арк. 59).

\section{The Teutonic Order}

Knights of the Teutonic Order were called to protect pilgrims into the Holy Land at the beginning of their history. The nature of the Order had been changed over time. Knights even broke celibacy, took care of feudal possessions, and even played dice. The grandmaster Ulrich von Jungingen (c.1360-1410) did not even like monks. They were further a danger as 'feudal lords' to Gentile Lithuanians with infidels and to Poles having a support of German Emperors and Apostolic See (Nicholson, 2004: 48). There is nothing left for the Poles, Lithuanians, and Ruthenians to join their efforts against the common enemy. The basics of unification were outlined by the Union of Krewo with dominance of the Catholic Kingdom of Poland (Frost, 2018: 50). The King of Poland Władysław II Jagiełło had started policy of patronage of the structures of the Latin Church in Rus' and Lithuania as an alternative to the activities of the Teutonic Order. In the meantime the flags of the Order obtained under Grunwald had been housed in the Lviv Cathedral up to November 11 ${ }^{\text {th }}, 1410$ (Kozytskyi, 2014: 42). Further, the Latin bishops of Rus' witnessed the conclusion of the Union of Horodło on October 2, 1413 (BKCz, Perg. 300.). Bishop of Chołm Jan Biskupiec (1417-1452), who was previously the monk of the Dominican Order, received the foundation of the Cathedral as a sign of victory of King Władysław II Jagiełlo in lawsuits with the Teutonic Order (BKCz, 11 IV Rkps: 531-538). The Council of Constance (14141418) even received the report from the Latin Metropolitan of Lviv Jan Rzeszowski (1414-1436) in the same year, who baptized the Gentiles of Žemaitija (Lewicki, 1891: 93-96). Also, the bishops of Kyiv and Kamianets namely Michał Trestka (1410-1429) and Zbigniew from Lapanów (1414-1423/1428) were witnesses when settling the treaty between the King Władysław II Jagiełło and the Danish King Eric VII (1439) which was directed against the Livonian Order which was the branch of the Teutonic Order (Barbashev, 2012: 112; Allmand, 1995: 679).

\section{Ottoman Threat}

The confrontation at a level "The Holy Roman Empire - the Crown of Poland" was also reflected in the example of confronting toward the threat of Ottoman 
Turks conquest of Europe. The future German Emperor Sigismund Luxemburg craved a revenge for the defeat at Nikopol on September 25, 1396. He created the Knight Order of Dragon to fight infidels and "schismatics" (Whelan, 2014: 86). King Sigismund had been not allowing in diplomatic way to take lands of Teutonic Order to Poles. He tried to break the Polish-Lithuanian political union by crowning the Grand Duke Vytautas the Great of Lithuania. The King Władysław II Jagiełło received the proposal from the Patriarch of Constantinople to expel the Ottoman Turks from the Byzantine possessions next year after the defeat at Nikopol (Mončak, 1987: 152). The Polish King even helped Constantinople with grain in 1415 (BJ, Rkps 33: 298r). In contrast to the pro-Hungarian bishop Nicholas Venatoris (1413-1418), the pro-Polish bishop Tomasz Ebner (14131420) was appointed in Moldova. Also, another Moldavian Bishop of Bai Johannes Ryza (†1438) had been instructed by the Pope Martin V (1417-1431) to find out why the marriage between the pro-Polish ruler of Moldova Alexander the Good (1400-1432) and the sister of the Drand Duke Vytautas the Great Ringala (1367/1369-1423/1430) was broken (Rosseti, 1905: 307-310). This Moldavian lord defended Kiliya from the Ottoman Turks. The conditional climax of the confrontation took place at the Congress of Monarchs at Lutsk in January 1429. The Latin bishop of Lutsk Andrzej of Płońsk (1425-1459) participated in it. King Sigismund paid homage to the relics presented by this bishop at the beginning of the Congress (BJ, Rkps 33: 361r). It was going to the coronation of the Grand Duke Vytautas the Great of Lithuania but Poles intercepted the crown in September 1430 and the Lithuanian ruler died next month (Graff, 2008a: 79).

\section{The Hussite Wars}

Origins of Hussiteism can be traced back to the teaching of John Wycliffe (c.1320s-1384) at the University of Oxford (Bettenson, 1967: 242-247). But to some extent it violated the Catholic rite and dogmas and therefore was rejected by the Fathers of the Council of Constance. As a result, the founder of Hussitism Jan Hus (c.1369-1415) was burned as a heretic (Baron, Pietras, 2003: 134-135). But this caused dissatisfaction with supporters of the idea of a national Church in the Kingdom of Bohemia. Czechs refused to recognize the German and Hungarian King Sigismund as their king and summoned the King Władysław II Jagiello and the Grand Duke Vytautas the Great to the Czech throne. Pope Martin V (14171431) was forced to declare several unsuccessful Crusades against Czech heretics. The conditional peace with the Hussites was concluded in Prague in 1433. Perheps, Bishop of Peremyshl Maciej Janina (1392-1419) was the first in the Latin Metropolitanate of Lviv who banned the activity of lollards under the diocesan statutes in June 1415 (Abraham, 1920: 53). Further, the Metropolitan of Lviv Jan Rzeszowski received inquisitorial authority in 1423 in the context of confrontation with Hussites (AGAD, MK, Nr. 4, Ser. 1, Sygn. 23: 567-569). The Metropolitan of Lviv also was involved in the gathering of tithes on the anti- 
Hussite Crusade which was to be started in spring of 1425 (Theiner, 1861: 3031 ). But the amount of the mandatory collection of 20,000 florins even in two years was unbearable for the Metropolitanate of Lviv. In his second assignment to the little know bishop of Chołm Andrzej de Laschis, the Pope reduced the amount by half (Theiner, 1861: 40). However, reports on the specific gathering and participation of natives from the Metropolitanate of Lviv in anti-Hussite campaigns on the side of Apostolic See and the Holy Roman Empire were not found. In contrast, the Bishop of Chołm Jan Biskupiec was willing to negotiate in the context of confrontation with the Teutonic Order with Hussites, who had adherents at least among Franciscan monks, Ruthenians and Moldovians (BJ, Rkps 33: 339r; Graff, 2008b: 45-46).

\section{The Lithuanian Civil War (The Wars of Švitrigaila)}

The King of Poland Władysław II Jagiełło had been hoped to obtain power over the Grand Duchy of Lithuania after the death of the Grand Duke Vytautas the Great. However, the Orthodox Lithuanian-Ruthenian nobility led by the Grand Duke Švitrigaila of Lithuania decided to separate from the Crown of Poland. Nobility of Polotsk, Vitebsk, Smolensk, Kyiv and Lutsk supported this action against which the military campaigns of the Polish nobility began. The Grand Duke Švitrigaila's allies were also the Livonian Order and the Golden Horde. After Volynians were allowed to practice the Orthodox faith, the election of the proPolish Grand Lithuanian Duke Sigismund Kęstutaitis (1432-1440), the extension of the Union of Horodło rights to Ruthenians, and burning at the stake Metropolitan of Kyiv and All Rus' Gerasim (1433-1435) the movement of Švitrigaila (b.1370-1452) had begun to lose force and support (BKCz, 15 IV Rkps: 211-213, 435-436). After the victorious battle for Poles at Wilkomierz (Ukmergè) on September 1, 1435, the Grand Duke Švitrigaila still had been had political support for three years yet, but eventually gave way (BJ, Rkps 33: 32v-33r). Regarding to bishoprics, probably the first to show loyalty to the Crown of Poland was the bishop of Kamianets, Paweł of Bojańczyc. He was the head of the conspiracy against the Lithuanian Governor Jonas Daugirdas (†c.1443), as a result of which Polish troops entered Kamianets, Skala and Chervonograd (BJ, Rkps 33: 381r$381 v)$. Also, the Pope Eugene IV (1431-1447) identified him as the mediator in reconciliation of the parties (Daniłowicz, 1862: 159). As a result, together with the bishops of Lviv, Chołm, Łuck, the bishop Paul of Bojańczyc witnessed the conclusion of the Peace of Brześć Kujawski on December 31, 1435 (MNK, VIIIrkps-193: 8v-10r; Dogiel, 1764: 133; Graff, 2010: 65). The bishop of Lutsk Andrzej also tried to show his devotion to the King Władysław II Jagiełło, but on the way he was robbed by the Polish military. But the King compensated him the damages in the tent of the government official of the Crown of Poland Jan Oleśnicki (c.1400-1460) near Lutsk (BJ, Rkps 33: 390r-390v). 
It was determined that bishops of the Latin Metropolitanate of Lviv were involved in conflicts with Tatars, the Teutonic Order, Hussites, Ruthenians and Ottoman Turks. It was found that the activities of the bishops were an alternative to the activities of the Teutonic Order in the region. These prelates of the Latin Church were involved in confrontation with the Order primarily through the missionary and diplomatic services. The bishops testified during the signing of the most important treaties of the Crown of Poland. During the conflicts with Hussites, the Inquisition Service and the Fiscal Crusade funding were added to the duties of the bishops. The local Latin bishop Paweł of Bojańczyc was the direct organizer of the change of government in Kamianets. The participation of the prelates in the fight against the threat of the Ottoman conquest was not vividly expressive.

\section{ARCHIVES}

ЦДІАЛ України - Центральний державний історичний архів України, м Львів [The Lviv State Historical Archive in Lviv].

AGAD - Archiwum Głuwny Akt Dawnych w Warszawie [The Central Archive of Ancient Documents in Warsaw].

BJ - Biblioteka Jagiellońska [Jagiellonian Library].

BKCz - Biblioteka Książąt Czartoryskich [The Princes Czartoryski Library].

IFS - Institut für Stadtgeschichte, Frankfurt am Main [Institute of Urban History, Frankfurt am Main].

MNK - Muzeum Narodowe w Krakowie [National Museum in Krakow].

\section{BIBLIOGRAPHY}

Барбашев А. Витовт. Последние двадцать лет княжения. 1410-1430 г2. Біла Церква: видавець Олександр Пшонківський, 2012, 256.

Войтович Л. Формування кримськотатарського народу. Вступ до етногенезу. Біла Церква: видавець Олександр Пшонківський, 2009, 214.

Збірник козацьких літописів. Густинський. Самійла Величка. Граб'янки. Упор.

В. Крекотень, В. Шевчук, Р. Іванченко. Київ: Дніпро, 2006, 977.

Зема В. Конциліаризм і витоки унійних процесів у Київській митрополії. Україна в Центрально-Східній Європі. Київ: Інститут історії України, Національна академія наук України, 2018, Вип. 18, 61-113.

Зіморович Б. Потрійний Львів. Leopolis Triplex. 2-ге вид. ред. Наталія Царьова. Львів: «Центр Європи», 2002, 248.

Івашко Р. Єпископат Львівської митрополії і військові конфлікти першої третини XV ст. VI Міжнародна наукова конференція «Україна і Велике князівство Литовське в XIV-XVIII ст.: політичні, економічні, міжнаціональні та соціокультурні відносини загальноєвропейському вимірі». 
Кам'янець-Подільський національний університет імені Івана Огієнка, 18-21 вересня 2019 р. Програма та тези доповідей. Київ: Інститут історії України НАН України, 2019, 46-48.

Каталог пергаментних документів Центрального Державного історичного архіву УРСР у Львові. 1233-1799. Ред. Олег Купчинський, Едвард Ружицький. Київ: Наукова думка, 1972, 676.

Козицький А. Нариси військової історії Львова XIII-XVIII cm. Leopolis Militans. Львів: Апріорі, 2014, 368.

Полехов С. Наследники Витовта. Династическая война в Великом княжестве Литовском в 30-е годы XV века. Ред. Б. Флоря. Москва: "Индрик", 2015, 712.

Русина О. Проблеми політичної лояльності населення Великого князівства Литовського у XIV-XVI ст. Український історичний журнал. Київ: Інститут історії України, Національна Академія Наук України, 2003, № 6, 3-16.

Яковенко Н. Нарис історії середньовічної та ранньомодерної України. 2-ге вид. Київ: Критика, 2005, 584.

Abraham W. Najdawniejsze statuty synodalne Archidiecezji Gnieźnieńskiej oraz statuty z rękopisu Oss. Nr. 1627. z uwzględnieniem materiałów zebranych przez ś. p. B. Ulanowskiego. Kraków: Nakładem Polskiej Akademji Umiejętności, 1920, 56. (Studja i materjały do historji Ustawodawstwa Synodalnego w Polsce Nr. 6).

Allmand E. The New Cambridge Medieval History. Cambridge: Cambridge University Press, 1995, vol. 7, 1072.

Codex diplomaticus Regni Poloniae et Magni Ducatus Lituaniae. Coll. Maciej Dogiel. Vilnae: Ex Typograhia Regia \& Reipubl. CC. RR. Scholarum Piarum, 1764, vol. 4, 548.

Codex epistolaris saeculi decimi quinti. Ed. Anatol Lewicki. Kraków: Akademia umiejętności, 1891. T. 2, 531. (Editionum Collegii Historici Academiae Literarum Cracoviensis. Nr. 46).

Documents of the Christian Church. Ed. by Henry Bettenson. London-New-YorkToronto: Oxford University Press, 1967, 456.

Dokumenty soborów powszechnych. Tekst łaciński, grecki, arabski, ormiański, polski. Ukł. ks. Ardakiusz Baron, ks. Henryk Pietras SJ. Kraków: Wydawnictwo WAM, 2003, T. III, 680.

Frost R. The Oxford history of Poland-Lithuania. Volume 1: The making of the PolishLithuanian Union, 1385-1569. Oxford: Oxford University Press, 2018, 591.

Graff T. Działalność polityczna Zbigniewa Oleśnickiego i polskiej hierarchii kościejnej w dobie tzw. burzy koronacyjnej. Folia Historica Cracoviensia. Kraków: Wydawnictwo Naukowe Uniwersytetu Papieskiego Jana Pawła II w Krakowie, 2008, 14, 75-85.

Graff T. Kościół $w$ Polsce wobec konfliktu z zakonem Krzyżackim $w$ XV wieku. Studium z dziejów kultury politycznej polskiego episkopatu. Kraków: Wydaw- 
nictwo Naukowe Uniwersytetu Papieskiego Jana Pawła II w Krakowie, 2010, 124.

Jefferson J. The Holy Wars of King Wladislas and Sultan Murad: The OttomanChristian Conflict from 1438-1444. Leiden: Brill, 2012, 514.

Medium Aеvит: Середні віки. Підручник з історії Середніх віків для історичних факультетів університетів. Ред. Леонтій Войтович. Львів: Тріада Плюс, 2010, 511.

Mončak I. Flontine Ecumenism in the Kyivan Church. Romae: Editiones Universitatis Catholicae Ucrainorum S. Clementis Papae, 1987, 376.

Nicholson H. The Crusades. Westport: Greenwood Publishing Group, 2004, 196.

Prokop K. Arcybiskupi haliccy i lwowscy obrzq̨dku łacińskiego. Szkice biograficzne. Biały Dunajec-Ostróg: Wołanie z Wołynia, 2010, 451. (Biblioteka «Wołania z Wołynia», T. 72).

Prokop K. Biskupi kamienieccy od średniowiecza do współczesności: szkice biograficzne. Biały Dunajec-Ostróg: Wołanie z Wołynia, 2007, 401. (Biblioteka «Wołania z Wołynia», T. 55).

Prokop K. Sylwetki biskupów łuckich. Biały Dunajec-Ostróg: Wołanie z Wołynia, 2001, 258. (Biblioteka «Wołania z Wołynia», T. 20).

Rosseti R. Despre unguri şi episcopiile Catolice din Moldova. Analele Academiei Române. 1905, 2/27, 247-322.

Skarbiec diplomatów papieskich, cesarskich, królewskich, książęcych, uchwał narodowych, postanowień różnych władz i urzędów posługujących do krytycznego wyjaśnienia dziejów Litwy, Rusi Litewskiej i ościennych im krajów. Ukł. Ignacy Daniłowicz. Wilno: W drukarni A. H. Kirkora, 1862, T. 2, 370.

Studium z dziejów kultury politycznej polskiego episkopatu. Kraków: Wydawnictwo Naukowe Uniwersytetu Papieskiego Jana Pawła II w Krakowie, 2010, 124.

Vetera Monumenta Poloniae et Lithuaniae gentiumque finitimarum historiam illustrantia. Ed. Augustino Theiner. Romae: Typis Vaticanis, 1860, t. 1, 788. (Monumenta Historica Poloniae).

Vetera Monumenta Poloniae et Lithuaniae gentiumque finitimarum historiam illustrantia. Ed. Augustino Theiner. Romae: Typis Vaticanis, 1861, t. 2, 782. (Monumenta Historica Poloniae).

Whelan M. Sigismund of Luxemburg and the Imperial Response to the Ottoman Turkish Threat, c. 1410-1437. Thesis submitted for the Degree of Doctor of Philosophy. London: University of London, 2014, 218.

\section{REFERENCES}

Abraham, 1920 - Abraham, W. (1920). Najdawniejsze statuty synodalne Archidiecezji Gnieźnieńskiej oraz statuty z rękopisu Oss. Nr. 1627. z uwzględnieniem materiałów zebranych przez ś. $p$. B. Ulanowskiego [The oldest synodal statutes of the Gniezno Archdiocese and statutes from the manuscript Oss. 
No. 1627. including materials collected by B. Ulanowski]. Kraków: Nakładem Polskiej Akademji Umiejętności. [in Latin, Polish].

Allmand, 1995 - Allmand, E. (1995). The New Cambridge Medieval History. (7). Cambridge: Cambridge University Press. [in English].

Barbashev, 2012 - Barbashev, A. (2012). Vitovt. Posliedniie dvadtsat liet kniazheniia. 1410-1430 hh. [Vitovt. The last twenty years of the reign. 1410-1430]. Reprinted. Bila Tserkva: vydavets Oleksandr Pshonkivskyi. [in Ukrainian and Russian].

Baron, Pietras, 2003 - Baron, A., Pietras, H., ed. (2003). Dokumenty soborów powszechnych. Tekst łaciński, grecki, arabski, ormiański, polski [Documents of General Councils. Text in Latin, Greek, Arabic, Armenian, Polish]. (3). Kraków: Wydawnictwo WAM. [in Latin, Greek, Arabian, Armenian, Polish].

Bettenson, 1967 - Bettenson, H., ed. (1967). Documents of the Christian Church. London-New-York-Toronto: Oxford University Press. [in English].

Dogiel, 1764 - Dogiel, M. ed. (1764). Codex diplomaticus Regni Poloniae et Magni Ducatus Lituaniae [Diplomatic codex of the Crown of Poland and the Grand Duchy of Lithuania]. (4). Vilnae: Ex Typograhia Regia \& Reipubl. CC. RR. Scholarum Piarum, 1764. [in English].

Graff, 2008a - Graff, T. (2008). Działalność polityczna Zbigniewa Oleśnickiego i polskiej hierarchii kościejnej w dobie tzw. burzy koronacyjnej [Political activity of Zbigniew Oleśnicki and the Polish Church hierarchy in the era of so-called "Coronation Storm"]. Folia Historica Cracoviensia, 14, 75-85. [in Polish].

Graff, 2008b - Graff, T. (2008). Biskupi monarchii jagiellońskiej wobec herezji husyckiej w I połowie XV wieku [Bishops of the Jagiellonian monarchy against the Hussite heresy in the first half of the $15^{\text {th }}$ century]. Nasza Przeszłość, (109), 37-54. [in Polish].

Graff, 2010 - Graff, T. (2010). Kościół w Polsce wobec konfliktu z zakonem Krzyżackim w XV wieku. Studium z dziejów kultury politycznej polskiego episkopatu [Church in Poland in the face of the conflict with the Teutonic Order in the $15^{\text {th }}$ century. A study of the history of the political culture of the Polish episcopate]. Kraków: Wydawnictwo Naukowe Uniwersytetu Papieskiego Jana Pawła II w Krakowie. [in Polish].

Ivashko, 2019 - Ivashko, R. (2019). Yepyskopat Lvivskoi mytropolii i viiskovi konflikty pershoi tretyny XV st. [Bishops of the Metropolitanate of Lviv and the military conflicts of the first third of the $15^{\text {th }}$ century]. VI Mizhnarodna naukova konferentsiia «Ukraina i Velyke kniazivstvo Lytovske $v$ XIV-XVIII st.: politychni, ekonomichni, mizhnatsionalni ta sotsiokulturni vidnosyny zahalnoievropeiskomu vymiri». Kamianets-Podilskyi natsionalnyi universytet imeni Ivana Ohiienka, 18-21 veresnia 2019 r. Prohrama ta tezy dopovidei, 2019, 46-48. [in Ukrainian]. 
Jefferson, 2012 - Jefferson, J. (2012). The Holy Wars of King Wladislas and Sultan Murad: The Ottoman-Christian Conflict from 1438-1444. Leiden: Brill. [in English].

Daniłowicz, 1862 - Daniłuwicz, I., ed. (1862). Skarbiec diplomatów papieskich, cesarskich, królewskich, książęcych, uchwał narodowych, postanowień różnych władz i urzędów posługujacych do krytycznego wyjaśnienia dziejów Litwy, Rusi Litewskiej i ościennych im krajów [Treasury of papal, imperial, royal, princely documents, national resolutions, resolutions of various authorities and offices serving to critically explain the history of Lithuania, Lithuanian Rus' and neighboring countries]. (2). Wilno: W drukarni A. H. Kirkora. [in Latin, Polish].

Kozytskyi, 2014 - Kozytskyi, A. (2014). Narysy viiskovoi istorii Lvova XIII-XVIII st. Leopolis Militans [Essays on Military History of Lviv of $13^{\text {th }}-18^{\text {th }}$ centuries]. Lviv: Apriori. [in Ukrainian].

Krekoten', Shevchuk, Ivanchenko, 2006 - Krekoten', V., Shevchuk, V., Ivanchenko R. (2006). Zbirnyk kozatskykh litopysiv. Hustynskyi. Samiila Velychka. Hrabianky [The Collection of Cossack Chronicles. Gustinsky. Samiilo Wielyczko. Hrabianka]. Kyiv: Dnipro. [in Ukrainian].

Kupchynskyi, Ruzhytskyi, 1972 - Kupchynskyi, O., Ruzhytskyi, E., ed. (1972). Kataloh perhamentnykh dokumentiv Tsentralnoho Derzhavnoho istorychnoho arkhivu URSR u Lvovi. 1233-1799 [Catalog of parchment documents of the Central State Historical Archives of the USSR in Lviv. 1233-1799]. Kyiv: Naukova Dumka. [in Ukrainian, Latin, Old Slavic].

Lewicki, 1891 - Lewicki, A., ed. (1891). Codex epistolaris saeculi decimi quinti [The Codex of documents of the $15^{\text {th }}$ century]. (2). Kraków: Akademia umiejętności. [in Latin].

Mončak, 1987 - Monchak, I. (1987). Flontine Ecumenism in the Kyivan Church. Rome: Editiones Universitatis Catholicae Ucrainorum S. Clementis Papae. [in English].

Nicholson, 2004 - Nicholson, H. (2004). The Crusades. Westport: Greenwood Publishing Group. [in English].

Poliekhov, 2015 - Poliekhov, S. (2015). Nasliedniki Vitovta. Dinastichieskaia voina v Velikom kniazhiestvie Litovskom v 30-ye hody XV vieka. Moskva: "Indryk". [in Russian].

Prokop, 2010 - Prokop, K. (2010). Arcybiskupi haliccy i lwowscy obrzadku łacińskiego. Szkice biograficzne [Latin Archbishops of Halych and Lviv. Biographical sketches]. Biały Dunajec-Ostróg: Wołanie z Wołynia. [in Polish].

Prokop, 2007 - Prokop, K. (2007). Biskupi kamienieccy od średniowiecza do współczesności: szkice biograficzne. Biały Dunajec-Ostróg: Wołanie z Wołynia, 2007. [in Polish].

Prokop, 2001 - Prokop, K. (2001). Sylwetki biskupów łuckich. Biały DunajecOstróg: Wołanie z Wołynia. [in Polish]. 
Rosseti, 1905 - Rosseti, R. (1905). Despre unguri şi episcopiile Catolice din Moldova [About the Hungarian and Catholic bishops of Moldova]. Analele Academiei Române, 2/27, 247-322. [in Latin, Romanian].

Rusyna, 2003 - Rusyna, O. (2003). Problemy politychnoi loialnosti naselennia Velykoho kniazivstva Lytovskoho u XIV-XVI st. [Problems of political loyalty of the population of the Grand Duchy of Lithuania in the XIV-XVI centuries]. Ukrainskyi istorychnyi zhurnal, (6), 3-16. [in Ukrainian].

Theiner, 1860 - Theiner, A. ed. (1860). Vetera monumenta Poloniae et Lithuaniae gentiumque finitimarum historiam illustrantia. (1). Romae: Typis Vaticanis. [in Latin].

Theiner, 1861 - Theiner, A. ed. (1861). Vetera monumenta Poloniae et Lithuaniae gentiumque finitimarum historiam illustrantia. (2). Romae: Typis Vaticanis. [in Latin].

Voitovych, 2009 - Voitovych, L. (2009). Formuvannia krymskotatarskoho narodu. Vstup do etnohenezu [Formation of the Crimean Tatar people. Introduction to ethnogenesis.]. Bila Tserkva: vydavets Oleksandr Pshonkivskyi, 2009. [in Ukrainian].

Whelan, 2014 - Whelan, M. (2014). Sigismund of Luxemburg and the Imperial Response to the Ottoman Turkish Threat, c. 1410-1437. Thesis submitted for the Degree of Doctor of Philosophy. London: University of London. [in English].

Yakovenko, 2005 - Yakovenko, N. (2005). Narys istorii serednovichnoi ta rannomodernoi Ukrainy [An Outline of History of the Medieval and Early Modern Ukraine]. 2-he vyd. Kyiv: Krytyka. [in Ukrainian].

Zema, 2018 - Zema, V. (2018). Kontsyliaryzm i vytoky uniinykh protsesiv u Kyivskii mytropolii [Conciliarism and the origins of unified processes in the Metropolitanate of Kiev]. Ukraina v Tsentralno-Skhidnii Yevropi, (18), 61113. [in Ukrainian].

Zimorovych, 2002 - Zimorovych, B. (2002). Potriinyi Lviv. Leopolis Triplex [Triple Lviv]. Lviv: Vydavnytstvo "Tsentr Yevropy". [in Ukrainian]. 